\title{
High-resolution mapping of large gas emitting mud volcanoes on the Egyptian continental margin (Nile Deep Sea Fan) by AUV surveys
}

\author{
S. Dupré $\cdot$ G. Buffet $\cdot$ J. Mascle $\cdot$ J.-P. Foucher $\cdot$ \\ S. Gauger - A. Boetius C. Marfia $\cdot$ The AsterX AUV Team • \\ The Quest ROV Team · The BIONIL scientific party
}

Received: 1 October 2008/ Accepted: 9 March 2009/Published online: 27 March 2009

(c) The Author(s) 2009. This article is published with open access at Springerlink.com

\begin{abstract}
Two highly active mud volcanoes located in 990-1,265 m water depths were mapped on the northern Egyptian continental slope during the BIONIL expedition of R/V Meteor in October 2006. High-resolution swath bathymetry and backscatter imagery were acquired with an autonomous underwater vehicle (AUV)-mounted multibeam echosounder, operating at a frequency of $200 \mathrm{kHz}$. Data allowed for the construction of $\sim 1 \mathrm{~m}$ pixel bathymetry and backscatter maps. The newly produced maps provide details of the seabed morphology and texture, and insights into the formation of the two mud volcanoes. They also contain key indicators on the distribution of seepage and its tectonic control. The acquisition of highresolution seafloor bathymetry and acoustic imagery maps with an AUV-mounted multibeam echosounder fills the gap in spatial scale between conventional multibeam data collected from a surface vessel and in situ video
\end{abstract}

S. Dupré $(\varangle)$ · J.-P. Foucher

Ifremer, Géosciences Marines, Plouzané, France

e-mail: stephanie.dupre@locean-ipsl.upmc.fr

S. Dupré · G. Buffet · J. Mascle

Géosciences Azur, Villefranche/Mer, France

S. Gauger

Fielax, Bremerhaven, Germany

A. Boetius

Max Planck Institute for Marine Microbiology, Bremen, Germany

C. Marfia - The AsterX AUV Team

Ifremer/GENAVIR, La Seyne/Mer, France

The Quest ROV Team

Marum, University of Bremen, Bremen, Germany observations made from a manned submersible or a remotely operating vehicle.

Keywords Mud volcanoes - Nile Deep Sea Fan · AUV · Bathymetry · Backscatter · Seafloor morphology · Eastern Mediterranean

\section{Introduction}

Fluid seepage in the eastern Mediterranean

The eastern Mediterranean Sea is subject to widespread seabed fluid seepage activity associated with mud volcanoes, authigenic carbonates and pockmarks. In the Mediterranean Sea, the first mud volcanoes were discovered in the accretionary prism of the western Hellenic arc (Cita et al. 1981) and in the central Mediterranean Ridge with the well known Olimpi mud volcano field (Cita and Camerlenghi 1990; Huguen et al. 2004; Ivanov et al. 1996). Since these discoveries, numerous fluid seepage related seabed structures have been identified in the Anaximander Mountains (Woodside et al. 1998), along the Florence Rise (Woodside et al. 2002; Zitter 2004), in the Levant Basin (Coleman and Ballard 2001), as well as in the Nile Deep Sea Fan (Bellaiche et al. 2001; Loncke et al. 2004; Mascle et al. 2001, 2006). Bathymetry and acoustic imagery maps of the seafloor obtained with shipborne multibeam echosounders (Loubrieu et al. 2001; MediMap Group et al. 2005) have played a key role in the discovery of fluid escape structures in the eastern Mediterranean Sea. They have been a trigger of several further investigations at a higher spatial scale using manned submersibles and remote operated vehicles (ROV), during which active processes of fluid seepage were investigated (Dupré et al. 2007; Huguen et al. 2005; Zitter et al. 2005). 
Geological controls on seep formation of the Nile Margin

Along the Mesozoic rifted continental margin off northern Egypt, sedimentary basins experienced rapid subsidence and high sedimentation, leading to the burial of thick accumulations of organic-rich sediments and, eventually, to the formation of hydrocarbons (Dolson et al. 2001). The deposition of evaporites during the Messinian (Hsü et al. 1973; Ryan 1978; Sage and Letouzey 1990) sealed the petroleum system. Hydrocarbons combined with water and mud were later released through faults crosscuting the Messinian evaporites and forming preferred conduits to the seabed (Loncke et al. 2004). In addition, during the Messinian, the margin was incised by large-scale canyons that were filled later by Pliocene sediments and have formed hydrocarbon reservoirs (Aal et al. 2001; Dolson et al. 2002). At present, the Nile Deep Sea Fan comprises more than $10 \mathrm{~km}$ of sediments (Aal et al. 2001; Camera et al. 2009).

New high-resolution dataset on the Nile Margin

The Nile Deep Sea Fan hosts numerous active fluid escape structures (Bayon et al. 2009; Huguen et al. 2009; Loncke et al. 2004; Mascle et al. 2006) including several large gas emitting mud volcanoes (Dupré et al. 2007). These latter are characterized by emissions of thermogenic methane and higher hydrocarbons (de Lange et al. 2006; Mastalerz et al. 2007). These mud volcanoes are located along the present day continental platform boundary, or close to the limit of the Messinian Platform (Fig. 1). Here we report on the results of a high-resolution swath multibeam survey of two of these mud volcano structures in the area, Amon and Isis, in combination with videographic surveying. All data were collected during the 2006 BIONIL expedition with $\mathrm{R} / \mathrm{V}$ Meteor (M70/2) using the Ifremer autonomous underwater vehicle (AUV) AsterX (Rigaud et al. 2004; Fig. 2) for the swath mapping survey and the deep-sea ROV Quest of MARUM, University Bremen (Ratmeyer and Gross 2003) for complementary in situ observations (Figs. 4, 5, 6, 7, 8, 9, 10, 11, 12, 13). Amon and Isis are both large mud volcanoes of 2.7 and $3.5 \mathrm{~km}$ in diameter (based on ship-borne bathymetry data, Dupré et al. 2007), and they are located in the eastern part of the Central Nile Deep Sea Fan, at $\sim 1,120$ and $990 \mathrm{~m}$ water depths, respectively (Figs. 1, 3). Based on earlier exploratory Nautile dives (Dupré et al. 2007) and side scan sonar surveys (Woodside et al. 2004), Amon and Isis mud volcanoes were chosen as priority sites to investigate and quantify fluid flow processes and associated cold seep ecosystems, as part of the ESF-coordinated EUROCORES EuroMargin MEDIFLUX Project (2003-2007). The use of the AUV
AsterX during BIONIL was critical in precisely locating scientific targets, in the planning of ROV dives and sampling operations from the ship, and subsequently in defining seep zonation and habitat dimensions.

\section{Methodology: AsterX AUV survey characteristics}

The AsterX AUV is $4.5 \mathrm{~m}$ long with a weight of $800 \mathrm{~kg}$ (Fig. 2). The autonomy of this AUV with its multibeam payload corresponds to $35 \mathrm{~km}$. A geological structure such as the Amon mud volcano with a surface area of $\sim 5 \mathrm{~km}^{2}$ and located at an average water depth of 1,190 m (Figs. 4, 5) can be fully surveyed in one AUV dive. The AUV back section integrates all the equipment of the basic vehicle (thruster, Doppler Velocity Log (DVL) navigation system, two localization beacons, Global Positioning System and radio antenna for surface telemetry). The middle section, which is the main hull, contains all the electronic systems together with eight lithium-ion batteries and one safety lead battery. The front section is mainly dedicated to external payloads, such as the swath multibeam Simrad EM2000 system (CNRS/Géosciences Azur), which was mounted during the BIONIL expedition. This multibeam system operates at a frequency of $200 \mathrm{kHz}$, allowing little penetration of the signal into the sediments. Therefore, AUVbackscatter amplitudes give direct information on the nature of the surface sediments and the local seafloor morphology, and are interpreted in this view. The bathymetric signal is sampled along 111 individual beams dispatched within an aperture of $120^{\circ}$. The real time position relative to the vehicle, corrected from pitch, roll and heave, is controlled by a Photonic Inertial Navigation System (PHINS). A GIS-based software, MIMOSA (MIssion Management for Subsea Autonomous vehicles; ${ }^{\circledR}$ Ifremer), was used for dive preparation and real time supervision. Two acoustics systems were installed on the R/V Meteor, the GAPS system (Global Acoustic Positioning System) from IXSEA for vehicle positioning and the MATS system (Multimodulation Acoustic Telemetry System) from SERCEL for acoustic telemetry during the dives. After the AUV-recovery on deck, the raw data are shortly transferred. Processing of the collected data (navigation, bathymetry and backscatter) led in a couple of hours to $2 \mathrm{~m}$ grid sized seafloor maps using the CARAIBES (CARtography Adapted to Imagery and BathymEtry of Sonars and multibeam echosounders) software ( ${ }^{\odot}$ Ifremer). Advanced processing, including conventional steps (tide correction, sound velocity correction, correction of bias of sensors as roll, pitch or heave and filtering of aberrant soundings) and specific corrections relative to the navigation were subsequently carried out and lead to the final detailed seafloor maps presented in Figs. 4a and 9a. 


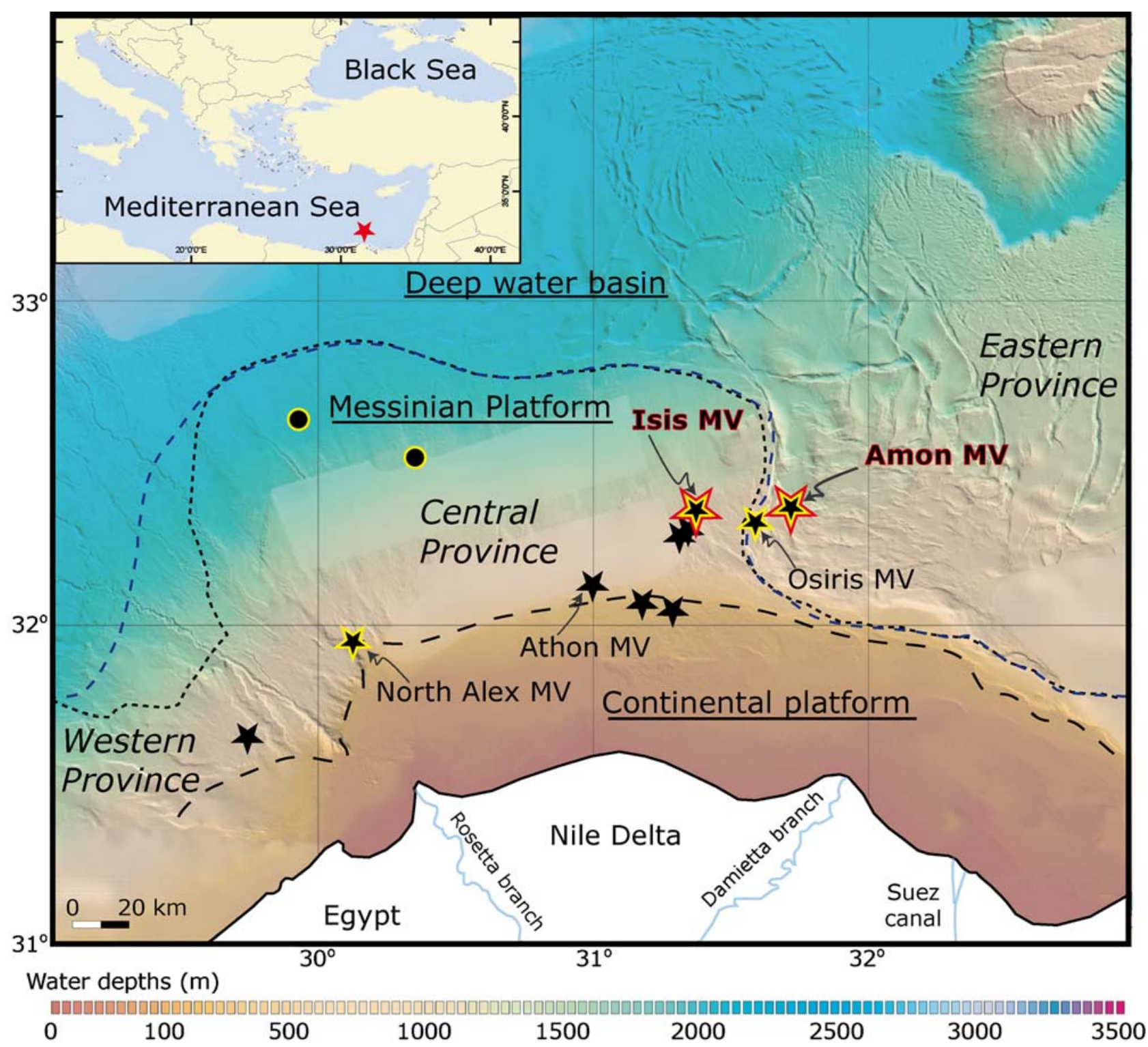

- - Present-day platform boundary (Loncke, 2002)

....-.- Messinian Platform boundary (Loncke et al., 2006)

-.- Southern limit of Messinian evaporites (Loncke et al., 2004)

* Large mud volcanoes located above gas chimneys

- Explored authigenic carbonate areas

* Areas explored with the Nautile submersible (2003)

\% Studied areas explored with the Quest ROV and the AsterX AUV (2006)

Fig. 1 Nile Deep Sea Fan shaded morphological map (Sardou and Mascle 2003) with indication of the deep-sea targets surveyed by the AsterX AUV and the Quest ROV during the BIONIL expedition in
2006. Inset shows the eastern Mediterranean map with location of the studied mud volcanoes (star). MV stands for Mud Volcano 


\section{(a)}

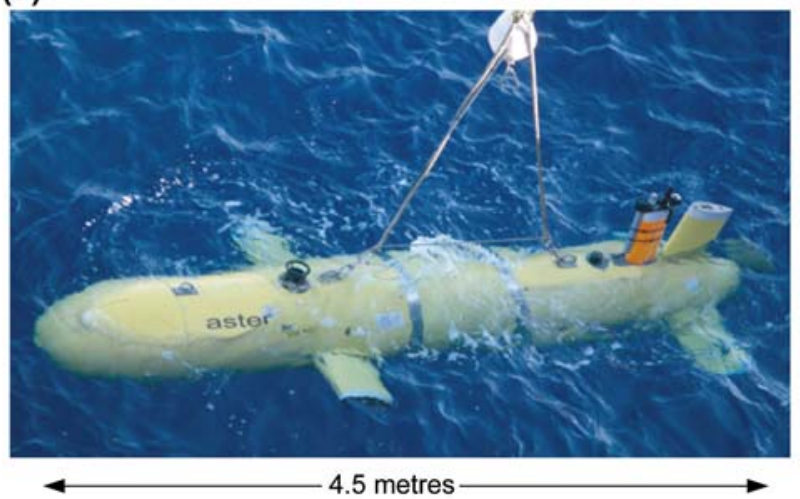

(b)

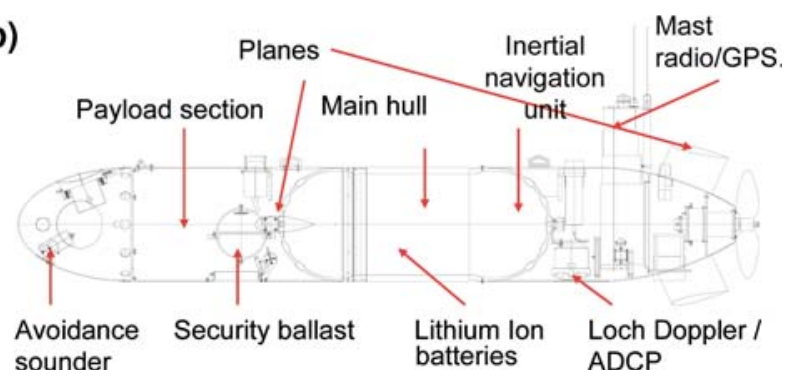

Fig. 2 a Picture of the AsterX AUV taken during recovery operation from the R/V Meteor during the BIONIL expedition (2006). b Corresponding sketch with the main AsterX components
Horizontal resolution

With the ability of the AUV to fly at a fixed distance above the seafloor, the mapping coverage is a function of the selected altitude. Here we chose $70 \mathrm{~m}$ above Amon and Isis mud volcanoes. Thus, with a beam spread angle of $120^{\circ}$ and survey lines spaced by $200 \mathrm{~m}$, a full seabed mapping coverage of Amon mud volcano was completed in $\sim 9 \mathrm{~h}$ and an optimal $2 \mathrm{~m}$ grid spacing map was obtained for the bathymetry (Fig. 4a). On local targets that are mainly covered by the central beams, the resolution can be decreased to $1 \mathrm{~m}$. The acoustic reflectivity from the backscatter signal is more finely sampled (Figs. 5a, 10). Metre-scale seafloor mapping permits a drastically different resolution compared to ship-borne acquired data. The example of the $50 \mathrm{~m}$ grid bathymetric map from the EM300 Simrad multibeam system is shown to demonstrate the contrast (Figs. 4a, 5b).

\section{Navigation}

The absolute geographical positioning strongly depends on the quality of the acoustical GAPS tracking. During the BIONIL dives, because of some dysfunctions in this system, the data were positioned with an overall uncertainty in

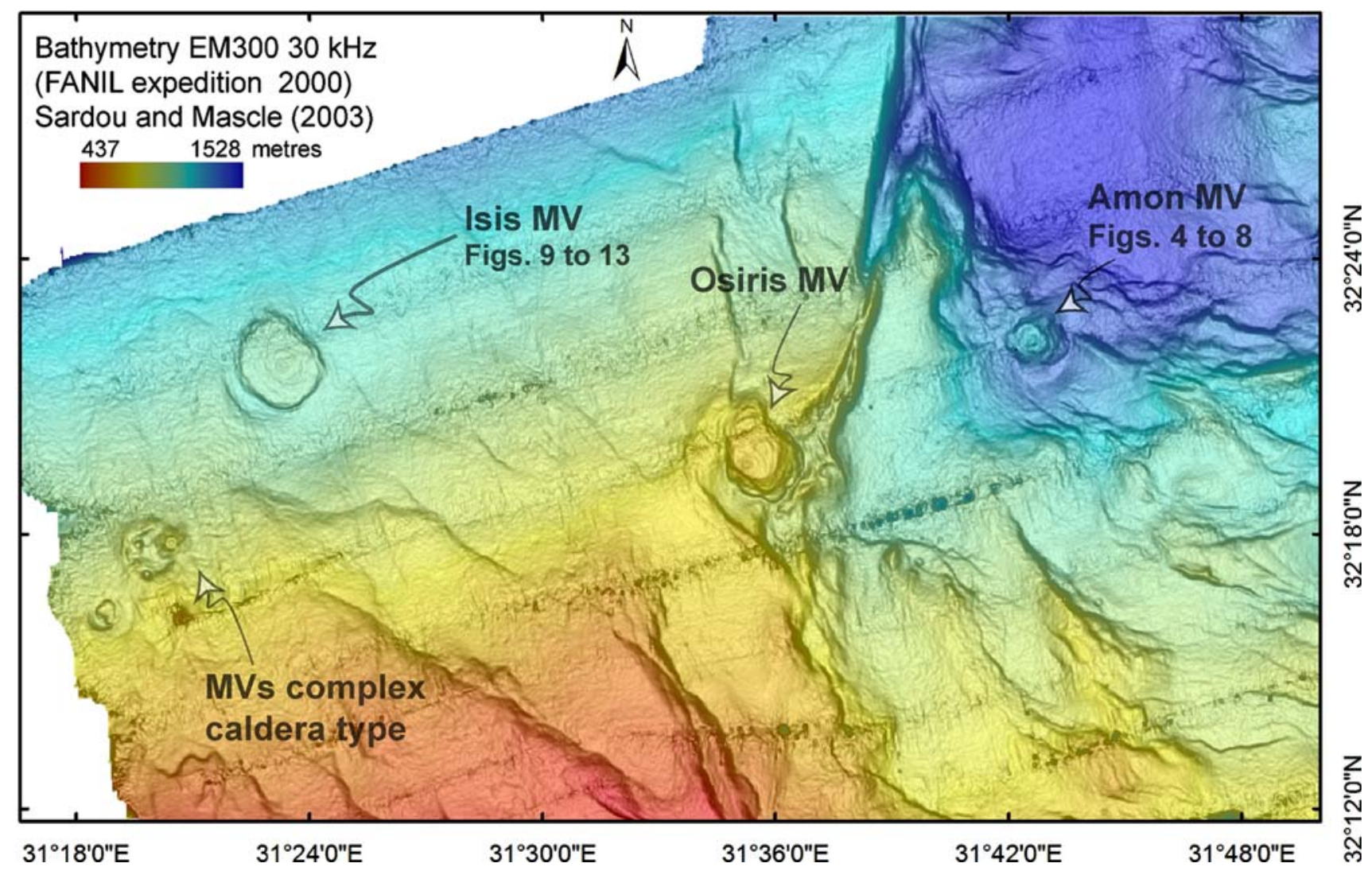

Fig. 3 Shaded bathymetric map of the eastern Central Nile Province (Sardou and Mascle 2003) comprising several active mud volcanoes. Amon and Isis were surveyed with the Quest ROV and the AsterX AUV during the BIONIL expedition in 2006 
Fig. 4 a $2 \mathrm{~m}$ grid shaded bathymetric map of Amon mud volcano located in the eastern part of the Central Nile Province below $\sim 1,120 \mathrm{~m}$ of water (see for location Figs. 1, 3) from AsterX AUV-acquired data (Simrad EM2000 system operated at $200 \mathrm{kHz}$ ) with $\mathbf{b}$ annotations
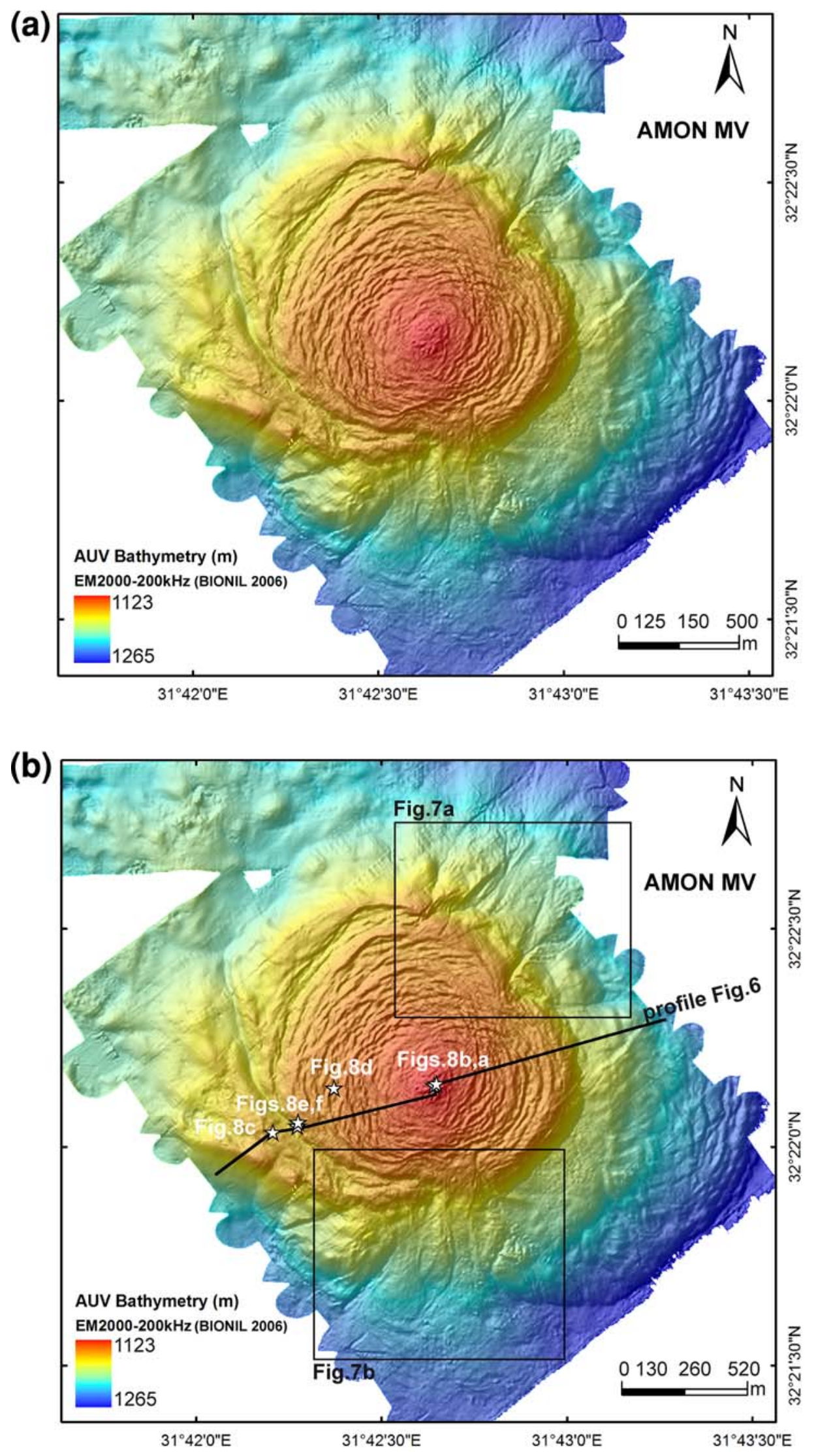
Fig. 5 a $1 \mathrm{~m}$ backscatter seafloor imagery of Amon mud volcano located in the eastern part of the Central Nile Province below $\sim 1,120 \mathrm{~m}$ of water (see for location Figs. 1, 3) from AsterX AUV-acquired data (Simrad EM2000 system operated at $200 \mathrm{kHz}$ ) and $\mathbf{b}$ $50 \mathrm{~m}$ grid shaded bathymetric map of the same mud volcano acquired from ship-borne multibeam data (Simrad EM300 system operated at $30 \mathrm{kHz}$ ) (a)

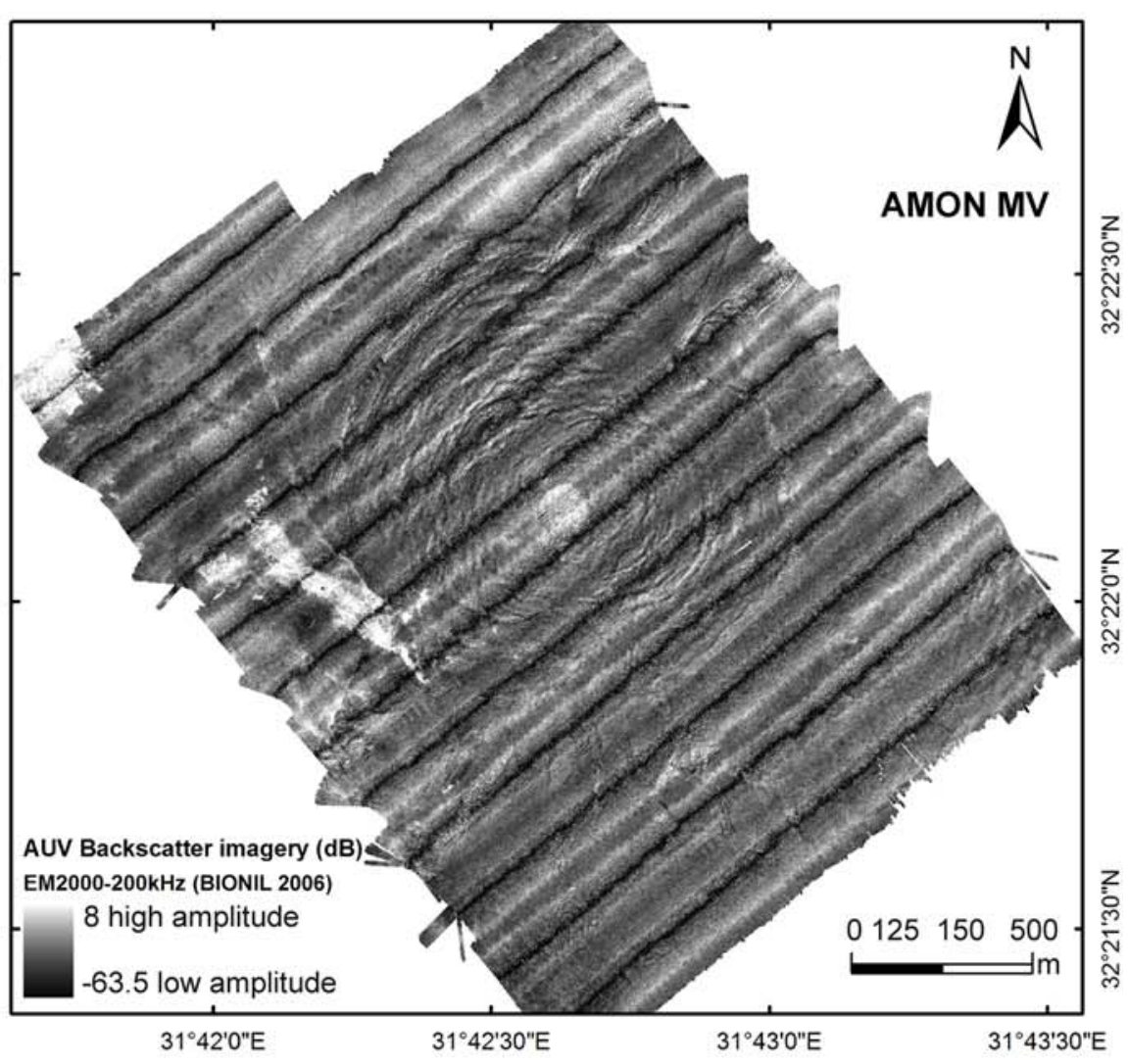

(b)

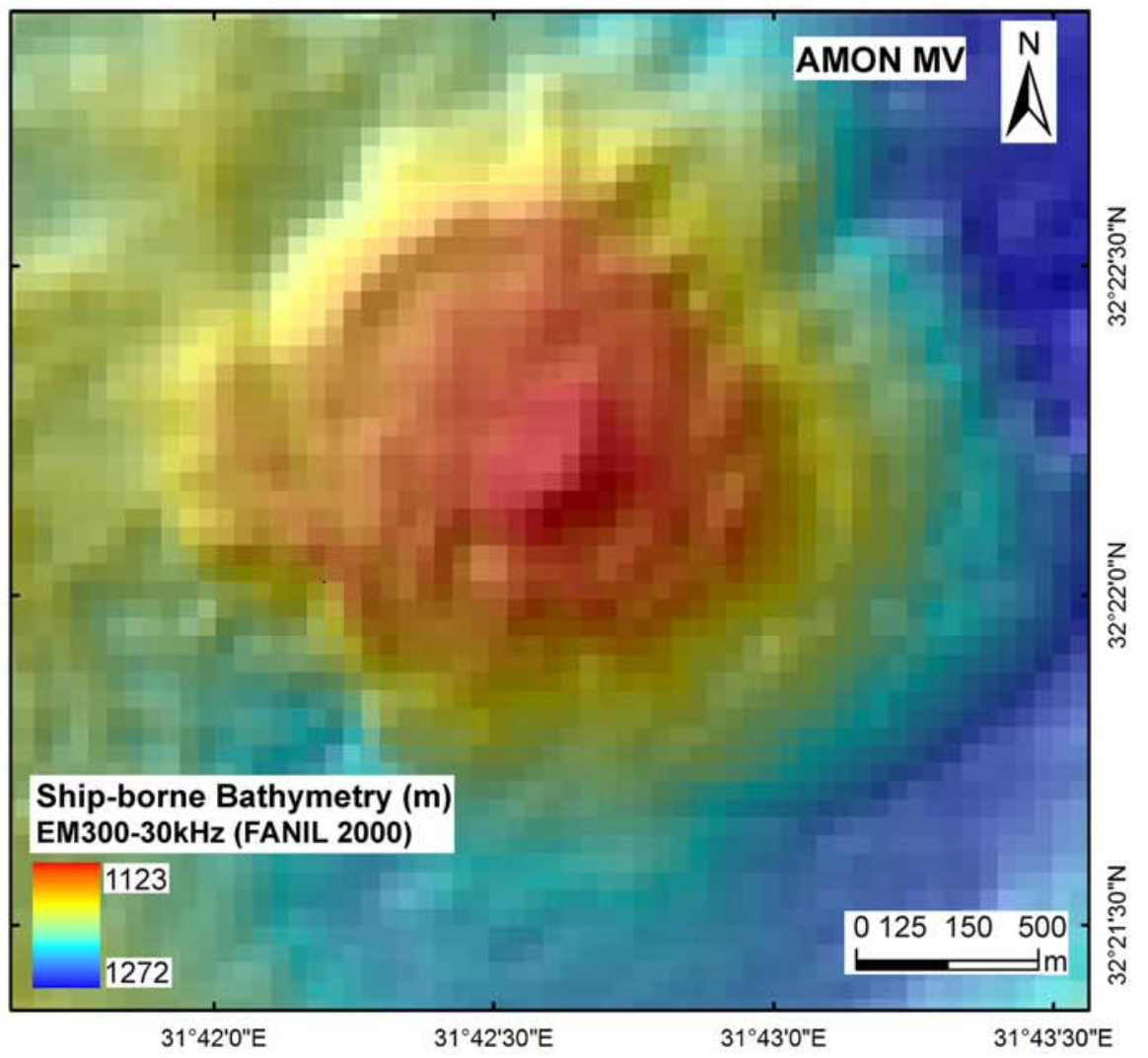


the order of metres (with maximum errors reaching locally more than $20 \mathrm{~m}$ ). However, insofar as the DVL bottom tracking continuously constrains the inertial positioning, the drift in relative positioning is $<2 \mathrm{~m} \mathrm{~h}^{-1}$. Although uncertainty in the absolute position remains, 2 or $1 \mathrm{~m}$ highresolution seafloor maps were obtained using interactive spatial shifts with the CARAIBES software $\left({ }^{\odot}\right.$ Ifremer). Additionally, Amon and Isis maps were rectified using bathymetry datasets obtained during previous expeditions (FANIL 2000 and NAUTINIL 2003).

\section{Vertical resolution}

The vertical resolution of the EM2000 system is theoretically much better than $0.5 \%$ of the distance below the transducers related to the central beams. The resolution increases to $1 \%$ on lateral beams. Because of difficulties in controlling the near bottom sound velocity, the accuracy of the bathymetric measurement can be estimated to be better than $0.5 \mathrm{~m}$ near the AUV track and $1 \mathrm{~m}$ over $50^{\circ}$ beam incidence. The latter estimation does not include the AUV depth sensor. The Amon dive was controlled by a Paroscientific pressure depth sensor, which is normally very sensitive $( \pm 1 \mathrm{~cm})$ and reliable. However, post processing of the data showed a strong calibration bias $(+25 \mathrm{~m}$ on average in the water depth measurement at a $1,000 \mathrm{~m}$ immersion) and a more severe defect in the measurement time delay. The latter is the cause of a non-reliable altitude correction when the AUV stabilizes its pitch. This results in a metric wavelength-undulation artifact and also erroneous vertical shifts of up to $2 \mathrm{~m}$ between contiguous lines, one uphill, the other downhill, over the more steeply slopes of the Amon mud volcano rim. The survey of the Isis mud volcano was performed using the on-board AsterX CTD (Conductivity Temperature Depth) sensor, which has a location opposite to the Paroscientific position. The CTD sensor is positioned in the nose, whereas the Paroscientific is positioned at the rear of the AUV. This difference in positions should have been taken into account, but because the measurements are considerably smoothed compared to the more sensitive Paroscientific sensor, the maps are less perturbed by the quick pitch changes.

\section{AUV survey data}

Amon mud volcano

\section{Concentric ridges and depressions around a central and seeping elevated dome}

The seafloor morphology of Amon mud volcano exhibits numerous concentric ridges and depressions (Fig. 4a).
These features have a mean wavelength of about $\sim 30 \mathrm{~m}$ and show amplitudes which are ranging on average from 2 to $3 \mathrm{~m}$ (Fig. 6). Subcircular around the centre of the mud volcano, they are however, interfingering in some places. The central dome, with a diameter of $125 \mathrm{~m}$, is slightly elevated, and rises $\sim 3 \mathrm{~m}$ above the rest of the mud volcano surface. The detailed bathymetry displays a summit with a chaotic relief while the seafloor imagery is clearly marked by high backscatter (Fig. 5a). The central anomalous high backscatter, with amplitudes up to $3 \mathrm{~dB}$, significantly contrasts with the low amplitude backscatter of the surrounding sediments. The average backscatter amplitude at the surface of Amon mud volcano is of $-13 \mathrm{~dB}$ (Figs. 5a, 6). The low backscatter amplitudes are caused by a relatively homogeneous mud breccia (1) composed of fine clay particles and numerous millimetric rock clasts with occasionally bigger ones (a few centimetres in size), and (2) already covered with hemipelagic sediments (Dupré et al. 2007). The high backscatter signal is mostly produced by metre-scale mud breccia blocks that make up parts of the central rough area (Fig. 8a). The homogeneous and structureless mud breccia which corresponds to a soft and unconsolidated material containing essentially millimetric rock clasts (some are authigenic carbonate concretions, Dupré et al. 2007; Gontharet et al. 2007) does not backscatter as much as energy as mud breccia with numerous and larger rock clasts (e.g., Amsterdam mud volcano located in the Anaximander Mountains area, Zitter et al. 2005). These rough mud breccia blocks are interspersed with smoother mounds, probably already shaped by erosion, and depressions (Fig. 8a, b). Based on in situ observations with the Nautile submersible (NAUTINIL expedition 2003, Dupré et al. 2007) and the Quest ROV (BIONIL expedition 2006), and analysis of the high-resolution bathymetry and backscatter maps (Figs. 4a, 5a), there is no evidence for any other sites of mud eruption at the surface of Amon mud volcano. The centre of the mud volcano coincides with a hot spot associated with elevated in situ sediment temperatures $\left(45^{\circ} \mathrm{C}\right.$ recorded at $10 \mathrm{~m}$ below the seafloor in 2003, Dupré et al. 2007), high gas content (free gas bubbles in the sediments) and elevated methane turnover of $>20 \mathrm{mmol} \mathrm{m}^{-2} \mathrm{~d}^{-1}$ (Felden, Lichtschlag, Wenzhöfer, Boetius; unpublished data).

\section{A major linear depression separating two different areas of the mud volcano}

The western part of Amon mud volcano is deformed by a NNW-SSE to N-S trending depression that separates the main body of the mud volcano from an area partly covered with authigenic carbonates. The bathymetry and backscatter AUV data clearly define distinct geological 


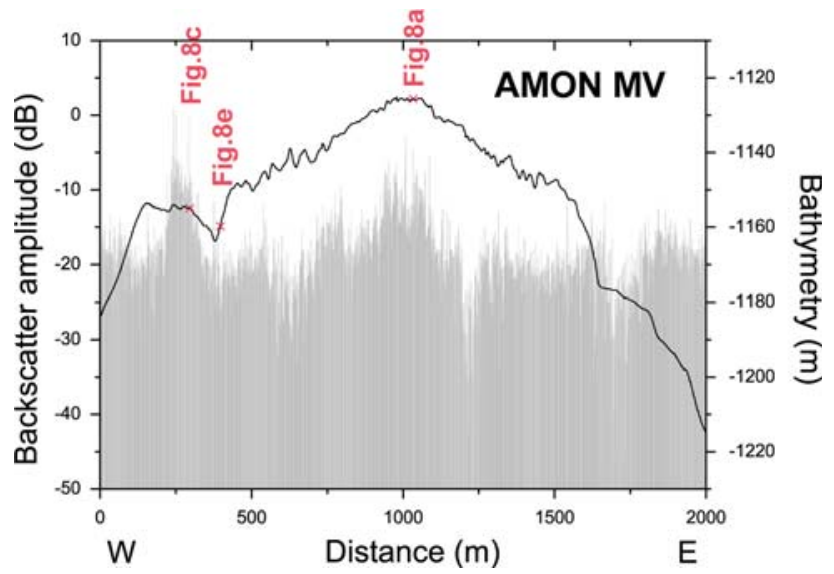

Fig. 6 AUV high-resolution bathymetry profile across the Amon mud volcano (see location in Fig. 4b) together with indication of the backscatter amplitude value

environments in the vicinity of this depression (Figs. 4a, $5 a, 6)$.

East of the depression, the seabed is mostly characterized by mud breccias covered with thin hemipelagic sediments. Here, the seabed is disturbed by numerous bioturbation mounds (Fig. 8d; Dupré et al. 2007). At the time of the BIONIL expedition in 2006, this type of habitat covered the largest faction of the total mud volcano area, $\sim 95 \%$ with $19.10^{5} \mathrm{~m}^{2}$. However, few places east of this depression are characterized by outcropping carbonates, as previously reported (NAUTINIL expedition 2003, Dupré et al. 2007). West of the depression, the seafloor morphology drastically changes with exposure of methanederived authigenic carbonates (Bayon et al. 2006; Gontharet et al. 2007) that are in places partly or completely draped with hemipelagic sediments. These carbonate constructions are well displayed by the new AUV data, in particular by the backscatter map (Fig. 5a) as a result of the high backscatter of the carbonates. Very high backscatter amplitudes were recorded, reaching $7 \mathrm{~dB}$, the highest value measured at the surface of Amon mud volcano. This significantly contrasts with the surrounding sediments that absorb more energy (Fig. 6). Based on the spatial distribution of the high backscatter and the weak penetration of the $200 \mathrm{kHz}$ signal, the area of outcropping carbonates is estimated to $\sim 83.10^{3} \mathrm{~m}^{2}$ (i.e., $\sim 4 \%$ when compared with the surface of Amon). Carbonate outcrops are of various types, including metre-scale chimney-like constructions or fractured domes (Fig. 8c), or plates partly covered by hemipelagic sediments (Fig. 8e). Away from these outcropping carbonates, the amplitude of the signal, although high, decreases quite rapidly.

The depression identified on the western side of Amon mud volcano is 1-km-long and 6-10 m deep (Figs. 4a, 6). The width of this V-shaped depression is $\sim 100 \mathrm{~m}$. Within (a) AUV Bathymetry (m) EM2000-200kHz (BIONIL 2006)
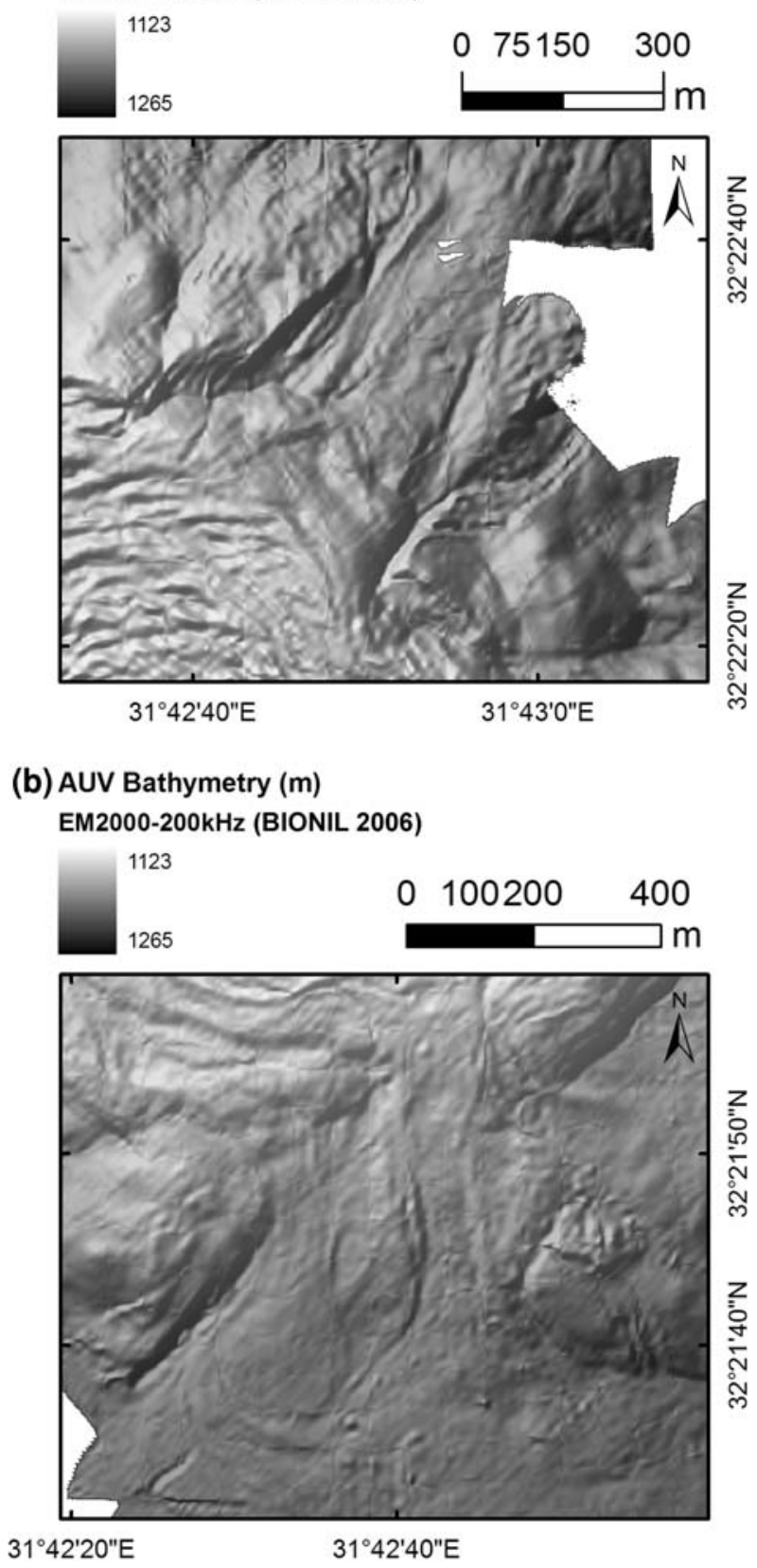

Fig. 7 Shaded high-resolution bathymetry maps exhibiting sedimentary instabilities identified at the edges of Amon mud volcano at a the northeastern and $\mathbf{b}$ southern border. The data are AUV-acquired data exposed in Fig. 4. See Fig. 4b for location

this depression and along its eastern flank, ROV observations showed a large bacterial mat (Fig. 8e) distributed along a N-S oriented strip of gassy, dark reduced sediments, with numerous chemosynthetic tubeworm and bivalve faunal communities (vestimentiferams and lammelibrachia) at its borders (Fig. 8f). The surface of these sediments that are affected by fluid flow extends $1-2 \mathrm{~m}$ in 
Fig. 8 Seafloor photos taken with the Quest ROV in 2006 at the surface of Amon mud volcano (see for position Fig. 4b, 6). a Chaotic mud extrusion structures juxtaposed to $\mathbf{b}$ smoother and older mud breccia metre-scale hills partly covered with microbial mats. c Methane-derived 'lithified' carbonates. d Bioturbation mounds that cover most of the mud volcano surface. e Along the NNW-SSE fault which separates the western side of the mud volcano, authigenic carbonates (right side) and source of the sulfur band showing blackish reduced sediments partially covered by bacterial mats (left side) in association with $\mathbf{f}$ chemosynthetic bivalves and tubeworms (vestimentiferams and lammelibrachia)
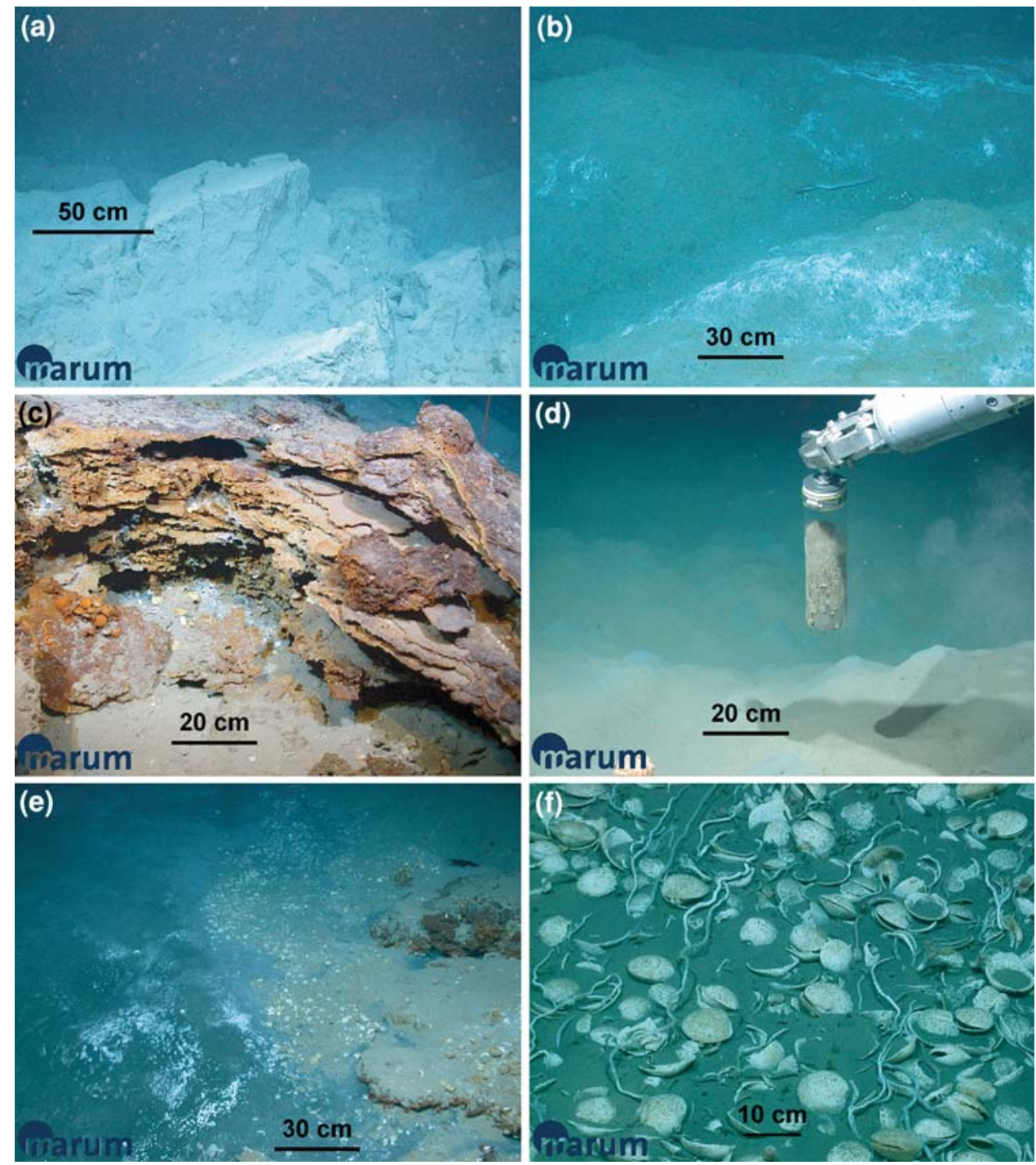

width and a few tens of $\mathrm{m}$ in length. This strip of reduced, sulfidic sediments ("sulfur band") that marks parts of the $\mathrm{V}$-shaped depression seems to correlate with a very low backscatter, distinctly identifiable on the AUV backscatter map (Figs. 5a, 6).

\section{Slide scars at the edges of the mud volcano}

The subcircular structure of Amon mud volcano is locally deformed at its edges by sedimentary slides. The scars of these slides are well imaged on the multibeam seafloor imageries, in particular on the $2 \mathrm{~m}$ high-resolution bathymetric maps (Figs. 4a, 7). The largest gravity induced sedimentary destabilizations are located northeast and south of Amon mud volcano where metre-scale mud breccia blocks are visible up to $\sim 1 \mathrm{~km}$ away from the edge of the mud volcano. At the northeastern border, the highresolution bathymetry maps reveal a 350-400 m wide corridor bounded by NE-SW lineations and along which mud breccia sediments appear to be destabilized. At the southern border, several sedimentary lobes are identified. The most western lobe is $500 \mathrm{~m}$ long with a surface of $<1 \mathrm{~km}^{2}$. These lobes are interpreted as mass transport deposits from mud breccia destabilizations initiated at the edge of the mud volcano where the flanks are known to be fairly abrupt (Dupré et al. 2007).

Isis mud volcano

\section{Overall seabed morphology}

The Isis mud volcano covers an area of $10.1 \mathrm{~km}^{2}$ and is located in more than $990 \mathrm{~m}$ of water (Figs. 1, 3). One-third of the mud volcano was surveyed with the AsterX AUV. The newly produced bathymetry and acoustic imagery maps of the seafloor exhibit similar morphological and 

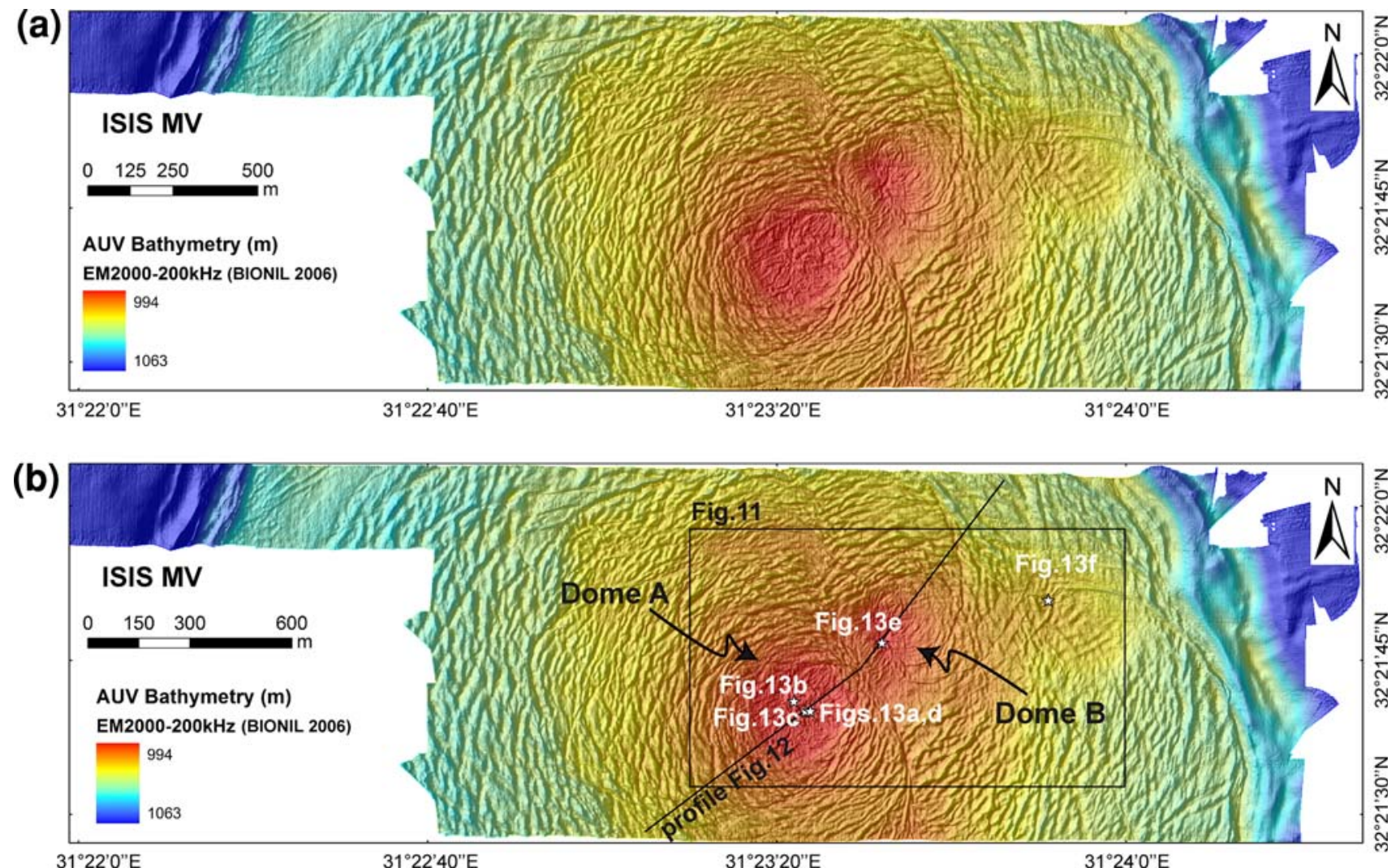

Fig. 9 a $1.5 \mathrm{~m}$ grid shaded bathymetric map of Isis mud volcano located in the eastern part of the Central Nile Province below $\sim 990 \mathrm{~m}$ of water (see for location Figs. 1, 3) from AsterX AUVacquired data (Simrad EM2000 system operated at $200 \mathrm{kHz}$ ) with b annotations. The dome $A$ is the main active emission site and unique

mud extrusion area discovered at the surface of the Isis mud volcano. The dome $B$ is interpreted as a former seeping site while the third elevated area (star location of Fig. 13f) appears to coincide with the intersection of two main sets of ridges (see details in the text)

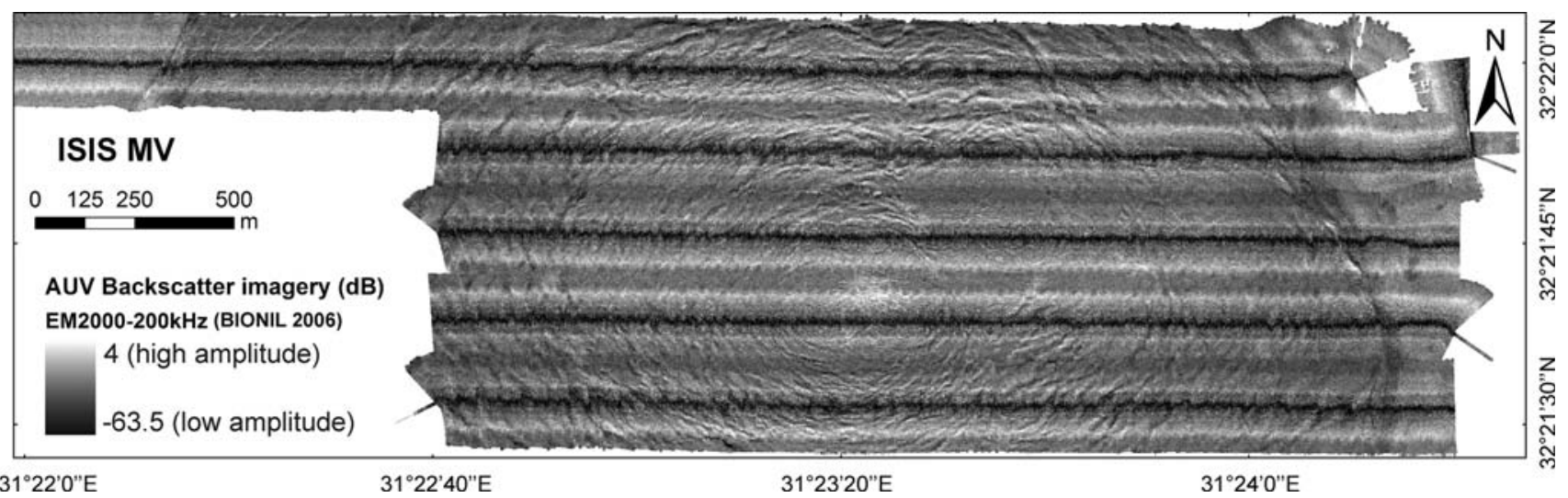

Fig. $101 \mathrm{~m}$ backscatter seafloor imagery of Isis mud volcano located in the eastern part of the Central Nile Province below $\sim 990 \mathrm{~m}$ of water (see for location Figs. 1, 3) from AsterX AUV-acquired data (Simrad EM2000 system operated at $200 \mathrm{kHz}$ )

backscatter features as those seen at Amon mud volcano (Figs. 4, 5, 9, 10, 11). Numerous ridges and depressions compose its surface (Figs. 9, 10, 11, 13). The features are not regularly distributed around the centre of the mud volcano, contrasting with Amon where they are fairly concentric. However, when compared with Amon mud volcano, the wavelength of the ridge and depression distribution on Isis is shorter, $17 \mathrm{~m}$ on average (versus $30 \mathrm{~m}$ on Amon, Figs. 4a, 6), and the amplitudes of these features are smaller, generally not exceeding $1 \mathrm{~m}$. 


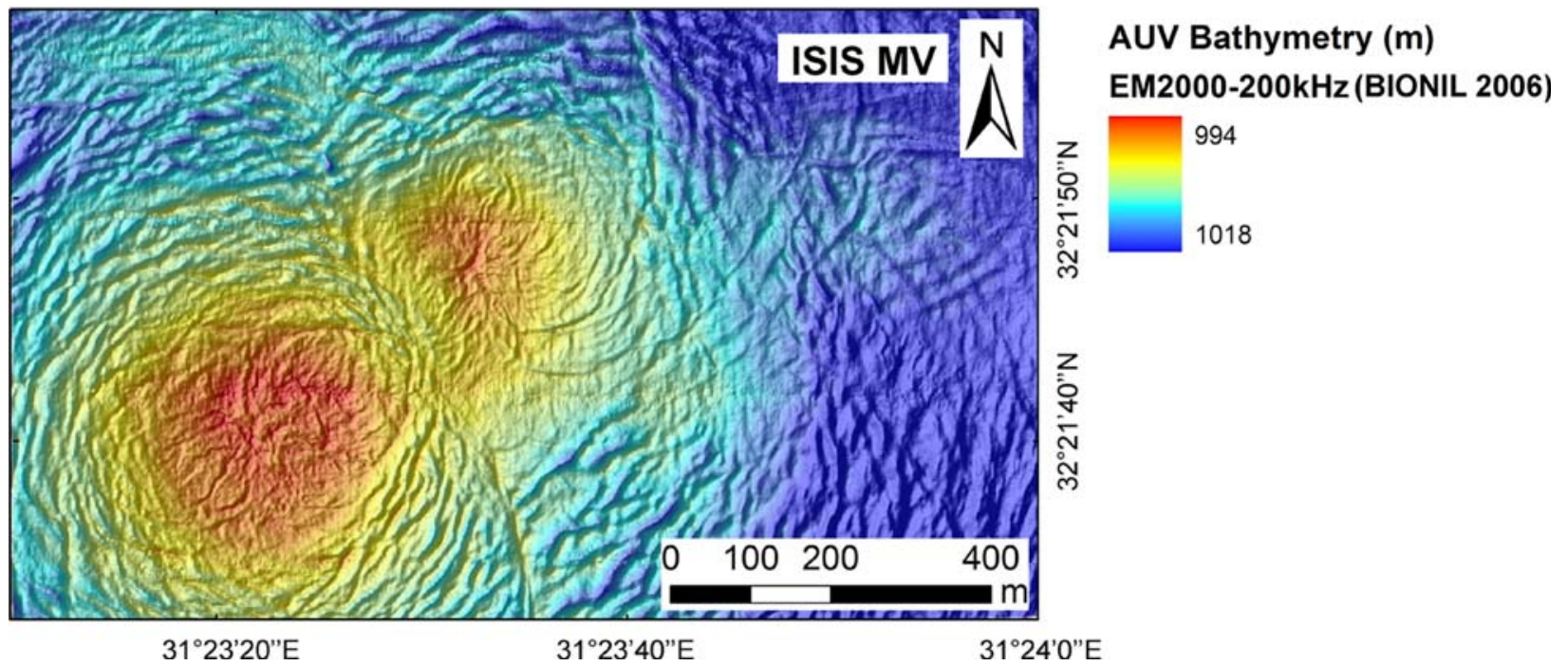

Fig. $111.5 \mathrm{~m}$ grid shaded bathymetric map focused on the two elevated central domes at Isis mud volcano located in the eastern part of the Central Nile Province below 990 m of water (see for location

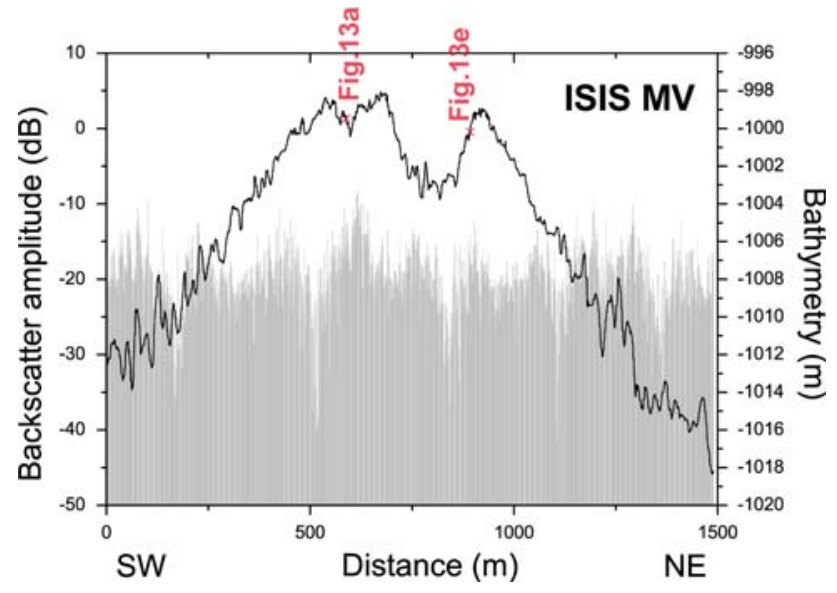

Fig. 12 AUV high-resolution bathymetry profile across the Isis mud volcano (see location in Fig. 9b) together with indication of the backscatter amplitude value

\section{Two distinct domes}

The new high-resolution bathymetric map clearly reveals the existence of two distinct slightly elevated areas at the surface of Isis mud volcano, one in the geometric centre of the edifice (dome A in Fig. 9b) and the other in an offset position to the $\mathrm{NE}$ of the centre (dome B in Fig. 9b). These domes are both 4-5 m high, with a diameter of 340 and $175 \mathrm{~m}$, respectively (Figs. 11, 12). The largest one, in the centre, corresponds to the unique mud eruption site discovered at the surface of Isis mud volcano (dome A in Fig. 9b), and exhibits a similar seafloor morphology (Fig. 13a, b) comparable to that of the active centre of Amon (Fig. 8a, b) with a chaotic distribution of mud breccia blocks on the summit (Fig. 11). At the Isis
Figs. 1, 3) from AsterX AUV-acquired data (Simrad EM2000 system operated at $200 \mathrm{kHz}$ )

central dome, high-resolution bathymetry data allow us to distinguish (1) numerous cracks that characterize highs and lows and (2) several topographic highs from which elongated bodies of mud breccia are radiating. At this centre, elevated temperatures were measured during the BIONIL expedition in 2006 (Feseker personal communication) and during the NAUTINIL (2003) and MIMES (2004) campaigns (at more than $40^{\circ} \mathrm{C}$ at $10 \mathrm{~m}$ below the seafloor, Dupré et al. 2007; Feseker et al. 2009). High methane concentrations in the water column and in the sediments characterize this central dome (see details in Mastalerz et al. 2007) with a seafloor disturbed by millimetric holes interpreted as resulting from gas expulsion (Fig. 13b). The second dome, located $340 \mathrm{~m}$ to the northeast of the main one (dome B in Figs. 9b, 11, 12), exhibits a disturbed seabed morphology with a major elongated and slightly curved ridge of $70 \mathrm{~m}$ in length, as well as elevated seafloor temperatures (however, twice as cool as the centre, Feseker personal communication). However, and in contrast to the central dome, ROV observations here showed no evidence for active seepage, such as gas bubbling spots, fresh mud breccia outcrops or chemosynthetic and microbial mats (see seafloor picture, Fig. 13e). Sediments there are only disturbed by numerous decimetre-scale bioturbation mounds (Fig. 13e) as observed for the vast majority of the mud volcano seabed (Dupré et al. 2007). The detailed bathymetry map displays a third slightly elevated area, located $425 \mathrm{~m}$ east of the second dome (Figs. 9b, 13f). This area, however, showed no sub-seafloor temperature anomaly (Feseker personal communication) and no visual indications of fluid and gas seepage during the ROV survey (BIONIL 2006; Fig. 13f) and the Nautile survey (NAUTINIL 2003; Dupré et al. 2007). 
Fig. 13 Seafloor photos taken with the Quest ROV in 2006 at the surface of Isis mud volcano (see for position Figs. 9b, 12). a Dark reduced sediment patches located at the main and central active dome and partly covered with white bacterial mats. b Central dome surface sediments disturbed by millimetric holes interpreted as resulting from gas expulsion. $\mathbf{c}$ and $\mathbf{d}$ Microrelief mud breccia structure superposed by small biogenic cones around the main active dome. e Sediments disturbed by biogenic mounds at the surface of the second and inactive dome. f Sediments disturbed by biogenic mounds and partly covered with thin hemipelagic cover, typically observed in the non seeping areas of the mud volcano
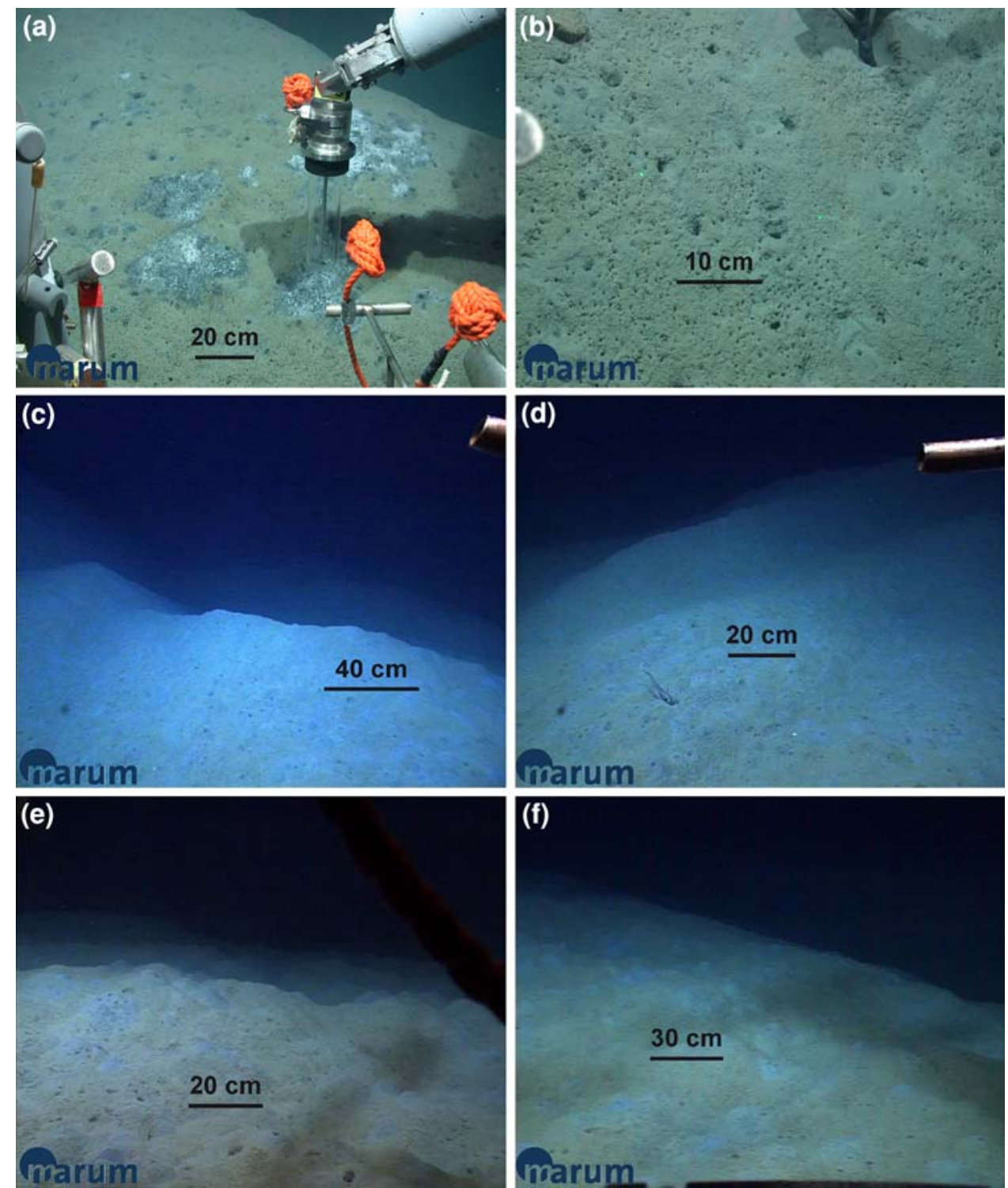

\section{Backscatter signature}

The backscatter amplitude spectrum of Isis mud volcano is narrow, when compared with Amon, with maximum recorded values of only $4 \mathrm{~dB}$ (Figs. 10, 12). The generally low and uniform backscatter of Isis appears to reflect the restricted diversity of the sedimentary texture (Fig. 13a-f). In the AsterX AUV surveyed areas (Fig. 9a), ROV observations did not find authigenic carbonates or bivalves and tubeworms, that would enhance the seabed backscatter if present. Lateral variations in the backscatter amplitude occur in association with (1) the numerous metre-scale ridges and depressions observed on the surface of Isis mud volcano, (2) the abrupt relief of the mud volcano edges (e.g., the eastern border in Fig. 10), and (3) the chaotic metre-scale mud breccia blocks. There is a relatively good correlation between the small-scale variation of the topography and the backscatter amplitude (see along the profile in Fig. 12). The newly acquired high-resolution backscatter map, covering one-third of the total surface of Isis, displays only one significantly higher backscatter area. Located on top of the central dome, this high backscatter patch covers a sub-circular area of $<50 \mathrm{~m}$ diameter, and is comprised within a wider zone of $<150 \mathrm{~m}$ diameter that corresponds to the disturbed and chaotic area.

\section{Discussion}

Mud extrusion and surface deformation pattern

The chaotic layout of the mud breccia blocks located at the centre of each investigated mud volcano suggests recent to 
ongoing deformation of the seabed. This deformation is most likely caused by subvertical mud extrusion and gas expansion in a conduit of lateral dimensions that would not exceed, in the upper part of the system at least, those of the rough area, and would be therefore $<125$ and $150 \mathrm{~m}$ in diameter at Amon and Isis mud volcanoes, respectively. In situ observations support a subvertical mud extrusion with subvertical striations that mark some walls of mud breccia blocks in the active centre of Amon mud volcano (Dupré et al. 2007).

The numerous depressions and ridges are interpreted as radial compression features, as also proposed for instance by the deformation pattern at the surface of the Atalante mud pie in the Barbados accretionary complex (Henry et al. 1990; Le Pichon et al. 1990). Based on side scan sonar data of the Atalante mud volcano, Le Pichon et al. (1990) interpreted the surface of the mud volcano to be composed of folds caused by the shortening of the surface upon a deflation of the central mud lake. This explanation is not satisfactory in the case of the Nile Deep Sea Fan mud volcanoes. The high-resolution bathymetry data reveal positive relief structures with distinct slightly elevated domes at the centre of the mud volcanoes. Additionally, we do not have any direct evidences from remote geophysical and in situ data for deflated or collapsing mud volcanoes. We suggest that the deformation pattern at the top surfaces of Amon and Isis mud volcanoes which corresponds to compressional morphological ridges and depressions are built in response to subvertical mud breccia extrusion at the centre of the mud volcanoes. The emplacement of newly extruded mud breccia material at the centre of the mud volcano leads the surrounding sediments to be radially pushed, and possibly results in sedimentary destabilizations at the edges of the mud volcanoes where the flanks are fairly abrupt (Dupré et al. 2007). Any spatial migration of the mud extrusion centre at the surface of the mud volcano would result in a new deformation pattern that would interfingering with the previous one. Thus, the analysis of the interfingering of these compresionnal features would provide evidence for successive and distinct mud extrusion pulses (see example of Isis mud volcano).

The observed differences in ridge and depression wavelengths and amplitudes between Amon and Isis may reflect differences (1) in rheological properties of the mud breccias and (2) in the stress fields at the two mud volcanoes. The volume of extruded mud breccia at Amon, relatively to its diameter, is much larger than at Isis (Dupré et al. 2007). Also, the slightly conical shape of Amon contrasts with the flat mud pie of Isis (Fig. 3). These features, as well as the less intensively deformed surface of Amon (Figs. 4a, 9a, 12), suggest different geomechanical behaviours at the two investigated mud volcanoes.
Spatial and temporal migration of the mud eruption sites

The AUV data provide geophysical evidence for spatial variations in the locations of the mud eruption sites. At Isis mud volcano, the two identified elevated domes are interpreted as successive mud eruption sites, with the most recent eruption event associated with the geometric centre of the mud volcano (dome A, Fig. 9b). There, the identified radial patterns may be interpreted as relatively recently erupted mud breccia flows. If so, the most recent mud eruption centre would be located at the southwestern border of the most elevated area while an older one could be located $\sim 90 \mathrm{~m}$ away at the northern border (Fig. 11). Based on backscatter imagery from ship-borne multibeam (Loncke et al. 2004) and 3D seismic coherency maps (Loncke 2002), the second most elevated area (dome B, Fig. 9b) had been initially suspected to coincide with a buried former seepage site. The AUV data and in situ ROV investigations partly confirm this interpretation but the well preserved morphology at the seabed and the sub-seafloor temperature gradient (Feseker personal communication), however, indicate a relatively recently active mud eruption area. The main seep activities have migrated laterally $\sim 300-350 \mathrm{~m}$, which attests to the temporal and spatial variability of the probable feeder conduits. The third elevation (Figs. 9b, 13f), of very low relief in contrast to the domes A and B (Fig. 9b), appears to coincide with the intersection of two main sets of ridges, oriented $\mathrm{N}-\mathrm{S}$ and W-E (Figs. 9a, 11). Based on the analysis of all available geophysical data and in situ observations (NAUTINIL 2003 and BIONIL 2006), there is no indication that this elevation may be associated with a former mud extrusion site. The backscatter sonar maps acquired with different frequency systems, and therefore, different sediment penetrations $(200 \mathrm{kHz}$ of the multibeam Simrad EM2000, Fig. 10 and $30 \mathrm{kHz}$ of the multibeam Simrad EM300, Loncke et al. 2004) do not show any acoustic anomalies indicative of seeping activity or mud breccia eruption. Moreover, 3D seismic coherency maps (Loncke 2002) which image deeper parts of the sedimentary column (corresponding to 5, 35 and $200 \mathrm{~ms}$ in TWT) do not show any evidence for a third conduit, although they clearly display the architecture of the conduit below the second dome (dome B, Figs. 9b, 11, 12).

Tectonic control on the seeping activity

Based on seismic data interpretation and ship-borne multibeam data analysis, Loncke et al. (2004, 2006) identified numerous listric faults and salt-related lineaments in the Eastern Nile Deep Sea Fan Province. The linear depression at the surface of Amon mud volcano was first identified on 
the basis of limited high-resolution bathymetry profiles along Nautile dive tracks (NAUTINIL expedition 2003, Dupré et al. 2007). The seabed expression of this depression is at present well imaged by the AUV-acquired data. This depression and the authigenic carbonate field as noted by Dupré et al. (2007) are aligned and linked to NW-SE faults identified both in the south and in the north of the mud volcano (Fig. 3). We therefore interpret the depression identified at the western side of Amon mud volcano as the surface expression of a fault, and we suggest that this fault is probably related to the surrounding fault system induced by salt tectonics and identified by Loncke et al. (2004, 2006). In consequence, the fault which separates the western side of Amon mud volcano controls the gas emissions and the precipitation of authigenic carbonates observed there.

Northwest of Amon, the detailed seafloor maps reveal a highly disturbed seafloor (Figs. 4a, 5a). The bathymetry map displays metre-scale mounds characterized by very high backscatter amplitudes that extend beyond these mounds. Because of their morphological and geophysical signature similarities, these features are interpreted as carbonate constructions. The seeping activity is not restricted to the surface of the mud volcanoes, but also occurs in their surroundings. In this region, the bathymetry acquired with ship-borne multibeam data (Sardou and Mascle 2003) and the mapping of salt-related lineaments and listric faults by Loncke et al. (2006) suggest that these seeps located off Amon mud volcano together with the ones associated with the NNW-SSE to NS running fault at the surface of the mud volcano are tectonically controlled by faults induced by the salt tectonics. Alternatively, the seeps located off the mud volcano may be associated with secondary fluid pathways possibly connected in depth to the feeder channels of the mud volcanoes.

Perspectives for deep sea investigations

\section{The AUV maps: a major contribution to deep-sea studies}

It is generally agreed that the acquisition of high-resolution seafloor bathymetry and acoustic imagery maps fills the large gap in spatial scale between multibeam data recorded from the sea surface and in situ and video observations from submersibles and ROVs. In addition to the coastal AUV surveys in water depths of a few hundreds of metres, the need to carry out high-resolution surveys in deeper water areas is essential not only as a guide to ROV-based deep ecosystem mapping and sampling investigations, but also for a number of studies of biological and geological processes, including hydrocarbon seepage at continental margins (Foucher et al. 2009), hydrothermal vents (Ferrini et al. 2007), coral reefs (Grasmueck et al. 2006) and slumps
(Lee and George 2004). Visual or video observations, restricted to the relatively limited areas covered during manned submersible (Dupré et al. 2007) or robot dives, can be extrapolated to broader areas of the seafloor when combined with the high-resolution maps produced from the AUV survey. This is exemplified in this paper by the possibility of defining the lateral extension of the central active areas on Amon and Isis, or that of the carbonate coverage to the southwestern outer edge of Amon mud volcano, or yet to have a broader view of the distinct centres of emission and the spatial arrangement of the mud breccia bodies on Isis. The availability of high-resolution seafloor imagery is not only valuable for geological and biological sampling strategies but also contributes to better identifying the morpho-structural environment of seep sites and therefore to gaining knowledge of such ecosystems. In combination with video camera observations, biogeochemical zonation can be established, in close relationship with the detailed bathymetry and the backscatter response of the seafloor given by the AUV maps, thus allowing distinct ecosystems or habitats to be proposed. This greatly serves quantitative approaches in ecology and geochemistry (Niemann et al. 2006).

\section{Monitoring seabed deformation}

AUV mapping can be used to monitor seabed deformation. For instance, Amon and Isis are two active mud volcanoes. How their surfaces evolve through time in relationship to potential pulses of mud and/or fluid emissions is not known. We suggest that repeated mapping with a AUV-borne or near seabottom-towed high-resolution multibeam echosounder, such as utilized during the BIONIL expedition, would open new opportunities. Comparing bathymetry and backscatter data grids ( $<1 \mathrm{~m}$ mesh size) over time may result in detecting (1) temporal changes that would indicate seafloor deformation and (2) potentially associated geohazards at selected fluid-escape sites (Foucher et al. 2009). As another example, earthquake monitoring in the Marmara Sea (Géli et al. 2008) could greatly benefit from repeated AUV surveys of the most active fluid sites. However, such future monitoring approaches involving AUV surveys would require even more accurate positioning of the AUV.

\section{Conclusions}

The seabed morphological features imaged by the newly AUV-acquired high-resolution backscatter and bathymetry maps of Amon and Isis mud volcanoes, together with previous available data and knowledge of seepage activity, partly allow the formation and evolution of the mud volcanoes to be reconstructed, and summarized as follows. 
Offshore northern Egypt, the mud volcanoes are clearly dominated at present by gas expulsion and subvertical mud breccia extrusion, with an associated main emission site located roughly at the centre of the mud structure and displayed in great details on AUV-bathymetry maps presented here. The associated seep area corresponds to a hot spot in terms of mud eruption, gas concentrations, temperatures and microbial activity. Characterized by high backscatter amplitudes derived from AsterX AUVacquired multibeam data, the seafloor is particularly chaotic and the sediments highly disturbed and gas-saturated. Restricted to relatively narrow and subcircular surfaces (maximum 125 and $150 \mathrm{~m}$ in diameter for the centres of Amon and Isis, respectively), these hot spots are connected at depth, at least for the uppermost part of the plumbing system, to gas expansion conduits of similar dimensions. Long term gas releases along some of these faults, which are clearly marked on seabed multibeam maps, contribute to the precipitation of methane-derived carbonates and the construction of metre-scale hardground edifices that attract chemosynthetic fauna. This type of seep activity occurs at the surface and off the flanks of the mud volcanoes and is clearly recorded on both bathymetry and backscatter AUVmaps. Some of these faults, for instance the NNW-SSE to NS running fault which separates the Amon mud volcano, correspond to listric faults induced by the salt tectonics and are possibly connected in the deeper part to faults within the crystalline crust. The seeping activity varies through time with the spatial migration of the main and secondary emission sites, according to the local and regional tectonic activity and sedimentation.

The consequences of the subvertical mud extrusion occurring at the centres of the mud volcanoes and that is very well displayed by the AUV-bathymetry and backscatter data, are the following (1) a high density of seeps associated with high gas content, (2) the expulsion of mud breccia blocks, (3) the deformation of the top surface of the mud volcanoes with the development of metre-scale compression ridges and depressions, and (4) the occurrence of sedimentary slides at the edges of the mud volcanoes.

\footnotetext{
Acknowledgments We would like to express many thanks to the scientists who participated in the BIONIL expedition, and the crews from the R/V Meteor. The BIONIL expedition was part of the ESFcoordinated EUROCORES EuroMargin MEDIFLUX Project (20032007), and in collaboration with the German Geotechnology program MUMM "Methane in the Geo/Biosphere: Turnover, Microorganisms and Metabolism" (03G0608A). MEDIFLUX aimed at a multidisciplinary study of fluid seepage through the seafloor of the Nile Deep Sea Fan and was carried out by a consortium of laboratories from France, Germany and the Netherlands. This work was made partly possible thanks to the support from the European Science Foundation (ESF) through contract No. ERAS-CT-2003-980409 of the European Commission, DG Research, FP6. This research was also supported by the HERMES project (Hotspot Ecosystem Research on the Margins of European Seas, http://www.eu-hermes.net), EC contract no GOCE-
}

CT-2005-511234, funded by the European Commission's Sixth Framework Programme under the priority 'Sustainable Development, Global Change and Ecosystems'. We thank Michael Strasser and an anonymous person for their constructive reviews of the manuscript.

Open Access This article is distributed under the terms of the Creative Commons Attribution Noncommercial License which permits any noncommercial use, distribution, and reproduction in any medium, provided the original author(s) and source are credited.

\section{References}

Aal AA, El Barkooky A, Gerrits M et al (2001) Tectonic evolution of the eastern Mediterranean Basin and its significance for the hydrocarbon prospectivity of the Nile Delta deepwater area. GeoArabia Manama 6:363-384

Bayon G, Loncke L, Dupré S et al (2009) Fluid seepage on an unstable margin: the case of the Centre Nile fan. Mar Geol. doi: 10.1016/j.margeo.2008.10.008

Bayon G, Henderson GM, Pierre C et al (2006) Temporal activity of fluid seepage on the Nile deep-sea fan inferred from U-Th dating of authigenic carbonates. CIESM Workshop Monograph. Fluids seepages/mud volcanism in the Mediterranean and adjacent domains 29:111-114

Bellaiche G, Loncke L, Gaullier V et al (2001) Le cône sous-marin du Nil et son réseau de chenaux profonds; nouveaux résultats (campagne Fanil). Comptes Rendus de l'Académie des Sciences, Série II. Sci Terre Planetes 333:399-404

Camera L, Ribodetti A, Mascle J (2009) Deep structures and seismic stratigraphy of the Egyptian continental margin from Multi Channel Seismic data. Geol Soc Spec Publ (in press)

Cita MB, Camerlenghi A (1990) The Mediterranean Ridge as an accretionary prism in collisional context. Atti del $75^{\circ}$ congresso nazionale della Societa Geologica Italiana "La geologia italiana degli anni' 90". Mem Soc Geol Ital 45:463-480

Cita MB, Ryan WBF, Paggi L (1981) Prometheus mud breccia; an example of shale diapirism in the Western Mediterranean Ridge. Ann Geologiques Pays Helleniques 30:543-570

Coleman D, Ballard R (2001) A highly concentrated region of cold hydrocarbon seeps in the southeastern Mediterranean Sea. GeoMar Lett 21:162-167. doi:10.1007/s003670100079

de Lange G, Mastalerz V, Dählmann A et al (2006) Geochemical composition and origin for fluid and gas fluxes at eastern Mediterranean mud volcanoes. CIESM Workshop Monograph. Fluids seepages/mud volcanism in the Mediterranean and adjacent domains 29:103-110

Dolson JC, Shann MV, Matbouly S et al (2001) The petroleum potential of Egypt. AAPG Mem 74:453-482

Dolson JC, Boucher PJ, Dodd T et al (2002) Petroleum potential of an emerging giant gas province, Nile Delta and Mediterranean Sea off Egypt. Oil Gas J 100:32-37

Dupré S, Woodside J, Foucher J-P et al (2007) Seafloor geological studies above active gas chimneys off Egypt (Central Nile Deep Sea Fan). Deep Sea Res Part I. Oceanogr Res Pap 54:1146-1172. doi:10.1016/j.dsr.2007.03.007

Ferrini VL, Fornari DJ, Shank TM et al (2007) Submeter bathymetric mapping of volcanic and hydrothermal features on the East Pacific Rise crest at $9^{\circ} 50^{\prime} \mathrm{N}$. Geochem Geophys Geosyst 8: Q01006

Feseker T, Dählmann A, Foucher J-P et al (2009) In situ sediment temperature measurements and geochemical porewater data suggest highly dynamic fluid flow at Isis mud volcano, eastern Mediterranean Sea. Mar Geol. doi:10.1029/2006GC001333 
Foucher J-P, Westbrook GK, Boetius A et al (2009) Structure and drivers of cold seep ecosystems. Oceanography (Wash DC) 22:92-109

Géli L, Henry P, Zitter T et al (2008) Gas emissions and active tectonics within the submerged section of the North Anatolian Fault zone in the Sea of Marmara. Earth Planet Sci Lett 274:3439. doi:10.1016/j.eps1.2008.06.047

Gontharet S, Pierre C, Blanc-Valleron MM et al (2007) Nature and origin of diagenetic carbonate crusts and concretions from mud volcanoes and pockmarks of the Nile deep-sea fan (eastern Mediterranean Sea). Deep Sea Res Part II. Top Stud Oceanogr 54:1292-1311. doi:10.1016/j.dsr2.2007.04.007

Grasmueck M, Eberli GP, Viggiano DA et al (2006) Autonomous underwater vehicle (AUV) mapping reveals coral mound distribution, morphology, and oceanography in deep water of the Straits of Florida. Geophys Res Lett 33:L23616. doi: 10.1029/2006GL027734

Henry P, Le Pichon X, Lallemant S et al (1990) Mud volcano field seaward of the Barbados accretionary complex; a deep-towed scan sonar. J Geophys Res 95:8917-8929. doi:10.1029/JB095 iB06p08917

Hsü KJ, Cita MB, Ryan WBF (1973) The origin of the Mediterranean evaporites. Initial Rep Deep Sea Drill Proj 13(Part 2):1203-1231

Huguen C, Foucher J-P, Mascle J et al (2009) Menes caldera, a highly active site of brine seepage in the eastern Mediterranean Sea: "In situ" observations from the NAUTINIL expedition (2003). Mar Geol. doi:10.1016/j.margeo.2009.02.005

Huguen C, Mascle J, Chaumillon E et al (2004) Structural setting and tectonic control of mud volcanoes from the Central Mediterranean Ridge (Eastern Mediterranean). Mar Geol 209:245-263. doi:10.1016/j.margeo.2004.05.002

Huguen C, Mascle J, Woodside J et al (2005) Mud volcanoes and mud domes of the Central Mediterranean Ridge: near-bottom and in situ observations. Deep Sea Res Part I. Oceanogr Res Pap 52:1911-1931. doi:10.1016/j.dsr.2005.05.006

Ivanov MK, Limonov AF, van Weering TCE (1996) Comparative characteristics of the Black Sea and Mediterranean Ridge mud volcanoes. Mar Geol 132:253-271. doi:10.1016/0025-3227(96) 00165-X

Le Pichon X, Foucher JP, Boulegue J et al (1990) Mud volcano field seaward of the Barbados accretionary complex; a submersible survey. J Geophys Res 95:8931-8943. doi:10.1029/JB095iB06 p08931

Lee YDE, George RA (2004) High-resolution geological AUV survey results across a portion of the eastern Sigsbee Escarpment. AAPG Bull 88:747-764. doi:10.1306/01260404011

Loncke L (2002) Le delta profond du Nil: structure et évolution depuis le Messinien. Géosciences Azur, Observatoire Océanologique de Villefranche sur mer. Thèse de doctorat de l'Université P. et M. Curie (Paris 6), $180 \mathrm{p}$

Loncke L, Mascle J, Fanil Scientific Parties (2004) Mud volcanoes, gas chimneys, pockmarks and mounds in the Nile deep-sea fan (eastern Mediterranean); geophysical evidences. Mar Pet Geol 21:669-689. doi:10.1016/j.marpetgeo.2004.02.004

Loncke L, Gaullier V, Mascle J et al (2006) The Nile deep-sea fan: an example of interacting sedimentation, salt tectonics, and inherited subsalt paleotopographic features. Mar Pet Geol 23:297315. doi:10.1016/j.marpetgeo.2006.01.001
Loubrieu B, Satra C, Cagna R (2001) Cartography by multibeam echo-sounder of the Mediterranean Ridge and surrounding areas. Ifremer/CIESM. 1/1 500 000, 2 maps. CIESM Editions

Mascle J, Zitter T, Bellaiche G et al (2001) The Nile deep sea fan; preliminary results from a swath bathymetry survey. Mar Pet Geol 18:471-477. doi:10.1016/S0264-8172(00)00072-6

WMascle J, Sardou O, Loncke L et al (2006) Morphostructure of the Egyptian continental margin: insights from Swath bathymetry surveys. Mar Geophy Res 27:49-59. doi:10.1007/s11001-0051559-x

Mastalerz V, de Lange GJ, Dahlmann A et al (2007) Active venting at the Isis mud volcano, offshore Egypt: origin and migration of hydrocarbons. Chem Geol 246:87-106. doi:10.1016/j.chemgeo. 2007.09.005

MediMap Group, Loubrieu B, Mascle J (2005) Morpho-bathymetry of the Mediterranean Sea, CIESM/Ifremer special publication, Atlases and Maps, 2 maps at 1/2 000000

Niemann H, Lösekann T, de Beer D et al (2006) Novel microbial communities of the Håkon Mosby mud volcano and their role as methane sink. Nature 443:854-858. doi:10.1038/nature05227

Ratmeyer V, Gross R (2003) Scientific applications for the electric QUEST WROV. Sea Technol 44:29-31

Rigaud V, Michel J-L, Ferguson JS et al (2004) First Steps in Ifremer's autonomous underwater vehicle program-A $3000 \mathrm{~m}$ depth operational survey AUV for environmental monitoring. Proceedings of the fourteenth (2004) International offshore and polar engineering conference, pp 203-208

Ryan WBF (1978) Messinian badlands on the southeastern margin of the Mediterranean Sea. Mar Geol 27:349-363. doi:10.1016/ 0025-3227(78)90039-7

Sage L, Letouzey J (1990) Convergence of the African and Eurasian Plate in the eastern Mediterranean. Petroleum and tectonics in mobile belts. Proceedings of the IFP exploration and production research conference, pp 49-68

Sardou O, Mascle J (2003) Cartography by multibeam echo-sounder of the Nile deep-sea Fan and surrounding areas (2 sheets). Special publication CIESM, Monaco

Woodside JM, Ivanov MK, Limonov AF (1998) Shallow gas and gas hydrates in the Anaximander Mountains region, eastern Mediterranean Sea. Geol Soc Spec Publ 137:177-193. doi:10.1144/ GSL.SP.1998.137.01.15

Woodside JM, Mascle J, Zitter TAC et al (2002) The florence rise, the western bend of the Cyprus Arc. Mar Geol 185:177-194. doi: 10.1016/S0025-3227(02)00194-9

oodside J, de Lange G, Dupré S et al (2004) Mimes An expedition on R/V Pelagia 13 June 2004-14 July 2004: a contribution to the MEDIFLUX project of EUROMARGINS, MIMES cruise report $81 \mathrm{p}$

Zitter T (2004) Mud volcanism and fluid emissions in eastern Mediterranean neotectonic zones. Netherlands research school of sedimentary geology thesis. Vrije University. $140 \mathrm{p}$

Zitter TAC, Huguen C, Woodside JM (2005) Geology of mud volcanoes in the eastern Mediterranean from combined sidescan sonar and submersible surveys. Deep Sea Res Part I. Oceanogr Res Pap 52:457-475. doi:10.1016/j.dsr.2004.10.005 